\title{
Temporal and Spatial Variation in Fish Larvae in Gamak Bay and Yeoja Bay, South Sea of Korea
}

\author{
Jung Hwa Ryu ${ }^{1}$, Jeong Bae Kim ${ }^{2}$ and Jin Koo Kim ${ }^{3, *}$ \\ ${ }^{1}$ Ryu Jung Hwa Marine Institute, Busan 614-803, Korea, ${ }^{2}$ Environment Research Division, \\ National Fisheries Research and Development Institute, Busan 619-705, Korea \\ ${ }^{3}$ Department of Marine Biology, Pukyong National University, Busan 608-737, Korea
}

\begin{abstract}
Fish larvae were collected monthly with an ichthyoplankton net from 18 stations (including four stations located in eelgrass beds) in Gamak Bay and Yeoja Bay, southern Korea, in 2007. In total, 33 species of fish larvae were collected, of which Engraulis japonicus (48.5\%), Tridentiger trigonocephalus (21.5\%), and Omobranchus elegans (9.2\%) were dominant. Dominant species varied seasonally: Hexagrammos otakii during December and January, Pholis nebulosa during January and March, Acanthogobius flavimanus in April, T. trigonocephalus in May, E. japonicus during June, July, September, and November, and Sillago japonica in August. Dominant species also differed between sites inside and outside the bays. Leiognathus nuchalis, O. elegans, and $T$. trigonocephalus were more abundant inside, while $H$. otakii was more abundant outside. From cluster analysis, three groups were identified according to sampling months (January-April, MaySeptember, and October-December) and two groups according to station (inside and outside bays). The occurrence of small larvae of almost all major fish species indicated that the bays were used as spawning and nursery grounds. An exception was Lateolabrax japonicus, whose specimens were relatively large ( $>19 \mathrm{~mm}$ TL), suggesting that this fish may spawn offshore, with its juveniles approaching the bays with growth.
\end{abstract}

Key words: Larval fish, Gamak Bay, Yeoja Bay, Variation, Eelgrass

\section{Introduction}

Ichthyoplankton has been investigated in estuaries or bays because these areas are easily influenced by human activity (i.e., pollution) (Lasker, 1987). In Korea, ichthyoplankton has been surveyed at various sites, including Jinhae Bay (Yoo et al., 1992), Yoja Bay (Yoo et al., 1993), Kwangyang Bay (Yoo and Cha, 1988; Cha and Park, 1994), Asan Bay (Kim et al., 1994), Sunchon Bay (Han et al., 2001), the Youngsan River estuary (Kim et al., 2003), and Yeongil Bay (Han et al., 2003). All of these studies focused on the role of bays as spawning or nursery grounds for fishes.

Yeoja Bay is characterized by its shallow water (average depth $\sim 5.4 \mathrm{~m}$ ) and narrow entrance, resulting in poor water exchange between areas inside and outside of the bay (Yoo et al., 1993; Kim et al., 2009). In contrast, Gamak Bay is characterized by

\footnotetext{
*Corresponding author: taengko@pknu.ac.kr
}

slightly deeper water (average depth $\sim 6.8-9 \mathrm{~m}$ ) and wide entrance, resulting in three different water masses (An et al., 2009). Thus, although these two neighboring bays are close to one another, they have some differences in topographic and oceanographic conditions. In a recent study, Kim et al. (2009) used dragnets to compare the community structure of young fish between the eelgrass beds in Yeoja Bay and those in Gamak Bay. The results showed no differences in community structure, but slight differences in the abundance and growth rate of Lateolabrax japonicus between the two neighboring eelgrass beds (Kim et al., 2009). It also documented that eelgrass beds play key roles as nursery grounds or shelters for fish such as L. japonicus, Leiognathus nuchalis, Pholis nebulosus, Takifugu niphobles, Tridentiger trigonocephalus, and Syngnathus schlegeli in the southern seas of Korea. However, only a few studies have examined the use of eelgrass beds as spawning grounds. Such research may provide important information and increase our understanding 
of the ecosystem structure of bays including eelgrass beds. Thus, this study aimed to clarify overall variations in fish larvae inside and outside two neighboring bays which include eelgrass beds.

\section{Materials and Methods}

Water temperature, salinity, $\mathrm{pH}$, and dissolved oxygen (DO) were measured and ichthyoplankton was collected by horizontal hauls using an RN80 net (diameter of net mouth $80 \mathrm{~cm}$, mesh size $330 \mu \mathrm{m}$ ) for 10 min once a month between January and December 2007 at 18 stations in the Yeoja and Gamak bays of Yeosu, in the South Sea of Korea (Fig. 1). The locations of stations were determined by the method of Margalef (1978). The volume of water filtered by the net was measured by a flow meter (Hydro Co., USA) attached at the mouth of the net. Collected samples were fixed in 5\% neutral formalin on board the research ship before being transferred to the laboratory for sorting, species identification, and measurement. Species were identified according to Okiyama (1988). We classified the stations into four areas: inside Yeoja Bay (Yi1, Yi2, Yi3, Yi4, Ye1, Ye2), outside Yeoja Bay (Yo1, Yo2, Yo3, Yo4), inside Gamak Bay (Gi1, Gi2, Ge1, Ge2), and outside Gamak Bay (Go1, Go2, Go3, Go4) to better understand the distribution characteristics of the fish larvae. Of these sampling sites, Ye1-Ye2 and Ge1$\mathrm{Ge} 2$ are located in eelgrass beds inside Yeoja Bay and Gamak Bay, respectively.

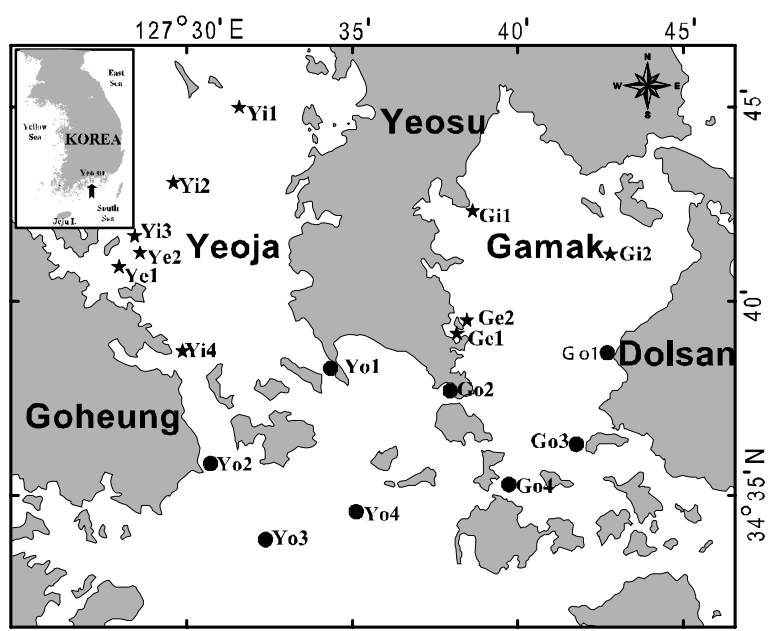

Fig. 1. Map showing the sampling stations to collect fish larvae in Gamak Bay and Yeoja Bay between January and December, 2007. Stars indicate the stations inside the bays and circles outside the bays.
On the basis of the number of larval fish caught each month, a species diversity index $\left(\mathrm{H}^{\prime}\right.$; Shannon and Weaver, 1948) was calculated, and a dendrogram was constructed using the unweighted pair group with arithmetic mean (UPGMA) method after the BrayCurtis similarity was calculated for cluster analysis (Zar, 1999). For the cluster analysis, species contribution to the grouping was evaluated according to SIMPER analysis. All statistical analyses were performed using PRIMER ver. 5.0.

\section{Results}

\section{Hydrology}

Sea surface temperature (SST) in the study area ranged from $7.2-24.9^{\circ} \mathrm{C}$ (mean $\pm \mathrm{SD}$ : $15.9 \pm 0.8^{\circ} \mathrm{C}$ ) and was lowest in January and highest in September (Fig. 2A). The sea surface salinity was 29.3-33.2 psu (mean \pm SD: $32.5 \pm 0.5 \mathrm{psu}$ ), with lowest values in September and highest values in January-April (Fig. 2B). Sea surface $\mathrm{pH}$ was 7.6-8.3 (mean \pm SD: $8.0 \pm$ 0.2 ) and was lowest in November-December (Fig. 2C). Sea surface DO ranged from $5.1-11.2 \mathrm{mg} / \mathrm{L}$ (mean \pm SD: $8.8 \pm 0.8 \mathrm{mg} / \mathrm{L}$ ), with lowest values in October and highest values in December (Fig. 2D).

\section{Larval fish species composition and distribution}

Fish larvae were classified into four orders, 24 families, and 33 species; 22 species were identified to the species level. Of these, Engraulis japonicus (48.63\%), T. trigonocephalus (21.33\%), and Omobranchus elegans (9.2\%) were predominant (Table 1). The dominant species varied seasonally with Hexagrammos otakii dominating during December and January, Pholis nebulosa during January and March, Acanthogobius flavimanus in April, T. trigonocephalus in May, E. japonicus during June and July and during September and November, and Sillago japonica in August. At Yeoja Bay, E. japonicus, L. nuchalis, O. elegans, T. trigonocephalus, and $P$. nebulosa were more abundant inside, while $H$. otakii was more abundant outside the bay (Table 2). At Gamak Bay, Gobiidae sp., O. elegans, $T$. trigonocephalus, and S. japonica were more abundant inside, and $H$. otakii was more abundant outside (Table 3).

\section{Relationship between larval fish occurrence and SST}

Samples collected during June and November 2007 contained 7-3,655 E. japonicus individuals $/ 100 \mathrm{~m}^{3}$, with total lengths ranging from 1.6 to $8.6 \mathrm{~mm}$ (3.7 \pm $1.4 \mathrm{~mm}$; Table 1). Of these, $87 \%$ were collected at 

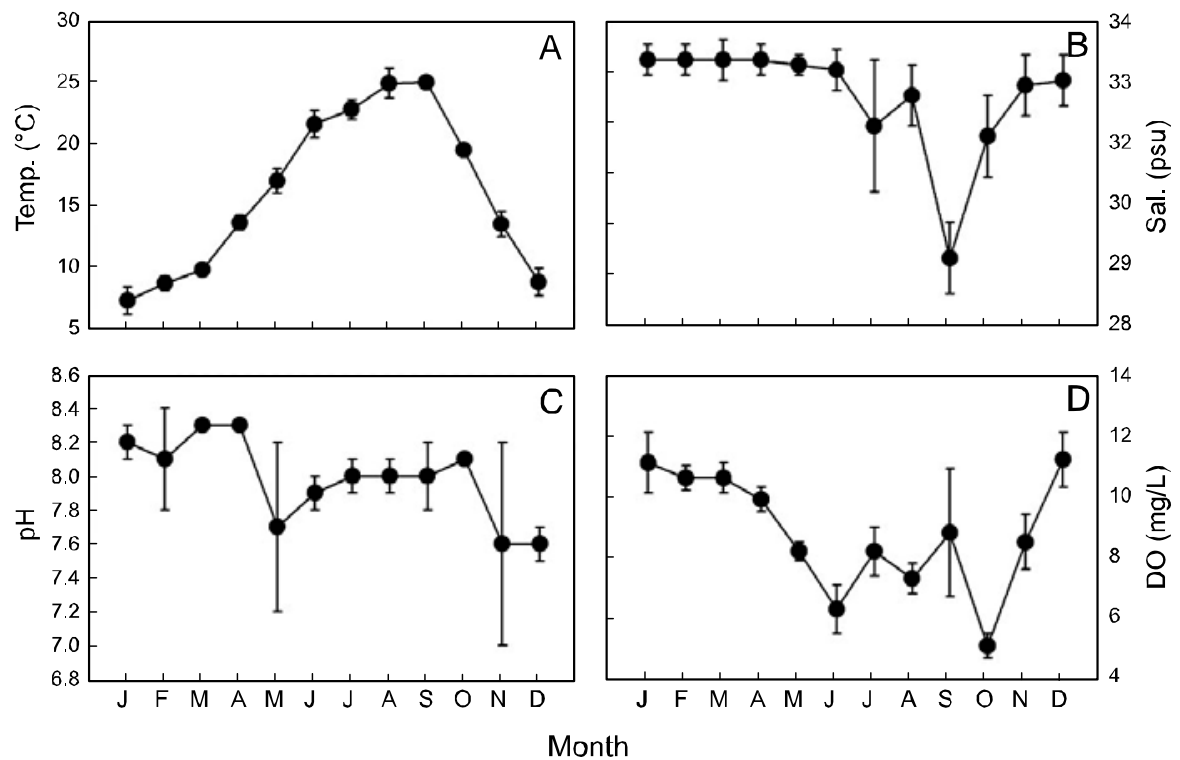

Fig. 2. Monthly variation of sea surface temperature (A), salinity (B), $\mathrm{pH}(\mathrm{C})$ and dissolved oxygen (D) in Gamak Bay and Yeoja Bay between January and December, 2007.

Table 1. Temporal variation in the number of individuals for larval fish collected in Gamak Bay and Yeoja Bay between January and December, 2007

\begin{tabular}{|c|c|c|c|c|c|c|c|c|c|c|c|c|c|}
\hline Scientific name & Jan & Feb & Mar & Apr & May & Jun & Jul & Aug & Sep & Oct & Nov & Dec & $\%$ \\
\hline Engraulis japonicus & 0 & 0 & 0 & 0 & 4 & 1,674 & 3,655 & 35 & 108 & 30 & 7 & 0 & 48.63 \\
\hline Clupea pallasii & 0 & 4 & 0 & 0 & 0 & 0 & 0 & 0 & 0 & 0 & 0 & 0 & 0.04 \\
\hline Konosirus punctatus & 0 & 0 & 0 & 0 & 0 & 3 & 0 & 0 & 0 & 0 & 0 & 0 & 0.03 \\
\hline Syngnathus schlegeli & 0 & 0 & 0 & 0 & 2 & 0 & 7 & 0 & 0 & 0 & 0 & 0 & 0.08 \\
\hline Sebastes inermis & 0 & 0 & 0 & 3 & 0 & 5 & 0 & 0 & 0 & 0 & 0 & 1 & 0.08 \\
\hline Platycephalus indicus & 0 & 0 & 0 & 0 & 0 & 0 & 0 & 1 & 0 & 0 & 0 & 0 & 0.01 \\
\hline Hexagrammos otakii & 27 & 0 & 0 & 0 & 0 & 0 & 0 & 0 & 0 & 0 & 6 & 508 & 4.77 \\
\hline Pseudoblennius cottoides & 0 & 0 & 0 & 0 & 0 & 1 & 0 & 0 & 0 & 0 & 0 & 0 & 0.01 \\
\hline Liparis tanakai & 3 & 0 & 0 & 0 & 0 & 0 & 0 & 0 & 0 & 0 & 0 & 3 & 0.05 \\
\hline Lateolabrax japonicus & 0 & 0 & 0 & 2 & 2 & 0 & 0 & 0 & 0 & 0 & 0 & 0 & 0.04 \\
\hline Sillago japonica & 0 & 0 & 0 & 0 & 0 & 0 & 141 & 174 & 3 & 0 & 0 & 0 & 2.81 \\
\hline Leiognathus nuchalis & 0 & 0 & 0 & 0 & 0 & 0 & 395 & 42 & 0 & 0 & 0 & 0 & 3.85 \\
\hline Haemulidae sp. & 0 & 0 & 0 & 0 & 0 & 0 & 0 & 1 & 0 & 0 & 0 & 0 & 0.01 \\
\hline Acanthopagrus schlegeli & 0 & 0 & 0 & 0 & 0 & 22 & 8 & 0 & 0 & 0 & 0 & 0 & 0.26 \\
\hline Pagrus major & 0 & 0 & 0 & 0 & 0 & 74 & 1 & 0 & 0 & 0 & 0 & 0 & 0.66 \\
\hline Terapon jarbua & 0 & 0 & 0 & 0 & 0 & 2 & 0 & 0 & 10 & 0 & 0 & 0 & 0.11 \\
\hline Stichaeidae sp. & 0 & 0 & 0 & 0 & 0 & 5 & 0 & 0 & 0 & 0 & 0 & 0 & 0.04 \\
\hline Ernogrammus hexagrammus & 23 & 4 & 0 & 0 & 0 & 0 & 0 & 0 & 0 & 0 & 0 & 0 & 0.24 \\
\hline Pholis nebulosa & 27 & 55 & 7 & 8 & 0 & 0 & 0 & 0 & 0 & 0 & 0 & 0 & 0.86 \\
\hline Enneapterygius sp. & 0 & 7 & 0 & 0 & 0 & 0 & 0 & 0 & 0 & 0 & 0 & 0 & 0.06 \\
\hline Blenniidae sp. & 0 & 0 & 0 & 0 & 0 & 0 & 0 & 0 & 0 & 0 & 3 & 0 & 0.03 \\
\hline Omobranchus elegan & 0 & 0 & 0 & 0 & 0 & 887 & 61 & 46 & 39 & 10 & 0 & 0 & 9.20 \\
\hline Repomucenus sp. & 0 & 0 & 0 & 0 & 0 & 0 & 0 & 0 & 0 & 3 & 0 & 0 & 0.03 \\
\hline Acanthogobius flavimanus & 0 & 0 & 0 & 174 & 0 & 73 & 0 & 0 & 0 & 0 & 0 & 0 & 2.18 \\
\hline Luciogobius sp. & 0 & 0 & 0 & 0 & 3 & 0 & 2 & 0 & 0 & 0 & 0 & 0 & 0.04 \\
\hline Synechogobius hasta & 0 & 0 & 0 & 4 & 0 & 0 & 0 & 0 & 0 & 0 & 0 & 0 & 0.04 \\
\hline Tridentiger trigonocephalus & 0 & 0 & 0 & 0 & 76 & 212 & 2,035 & 92 & 3 & 0 & 0 & 0 & 21.33 \\
\hline Gobiidae sp. & 0 & 0 & 0 & 0 & 4 & 334 & 0 & 12 & 0 & 0 & 0 & 0 & 3.09 \\
\hline Scomber japonicus & 0 & 0 & 1 & 22 & 0 & 0 & 0 & 0 & 0 & 0 & 0 & 0 & 0.20 \\
\hline Paralichthyidae sp. & 0 & 0 & 0 & 0 & 0 & 0 & 8 & 0 & 0 & 0 & 0 & 0 & 0.07 \\
\hline Pleuronectidae sp. & 0 & 0 & 0 & 0 & 0 & 0 & 0 & 0 & 0 & 2 & 0 & 25 & 0.24 \\
\hline Cynoglossidae sp. & 0 & 0 & 0 & 0 & 0 & 0 & 71 & 9 & 5 & 0 & 0 & 0 & 0.75 \\
\hline Unidentified sp. & 0 & 0 & 0 & 0 & 0 & 5 & 15 & 0 & 0 & 0 & 0 & 0 & 0.18 \\
\hline No. of species & 4 & 4 & 2 & 6 & 6 & 13 & 12 & 9 & 6 & 4 & 3 & 4 & \\
\hline$\%$ & 0.71 & 0.62 & 0.07 & 1.88 & 0.80 & 29.1 & 56.4 & 3.63 & 1.48 & 0.40 & 0.14 & 4.74 & 100 \\
\hline
\end{tabular}


Table 2. Spatial variation in the number of individuals for larval fish collected in Yeoja Bay between January and December, 2007

\begin{tabular}{|c|c|c|c|c|c|c|c|c|c|c|}
\hline \multirow{2}{*}{ Scientific name } & \multicolumn{4}{|c|}{ Inside } & \multicolumn{2}{|c|}{ Eelgrass } & \multicolumn{4}{|c|}{ Outside } \\
\hline & Yi1 & Yi2 & Yi3 & Yi4 & Ye1 & Ye2 & Yo1 & Yo2 & Yo3 & Yo4 \\
\hline Engraulis japonicus & 362 & 341 & 687 & 125 & 18 & 998 & 514 & 25 & 96 & 39 \\
\hline Konosirus punctatus & 0 & 0 & 3 & 0 & 0 & 0 & 0 & 0 & 0 & 0 \\
\hline Syngnathus schlegeli & 0 & 0 & 0 & 0 & 0 & 0 & 2 & 0 & 0 & 0 \\
\hline Sebastes inermis & 0 & 0 & 0 & 0 & 0 & 0 & 5 & 1 & 0 & 0 \\
\hline Hexagrammos otakii & 0 & 1 & 16 & 7 & 0 & 13 & 135 & 45 & 50 & 11 \\
\hline Pseudoblennius cottoides & 0 & 0 & 0 & 0 & 0 & 0 & 0 & 0 & 1 & 0 \\
\hline Liparis tanakai & 1 & 0 & 0 & 0 & 0 & 0 & 3 & 0 & 0 & 0 \\
\hline Sillago japonica & 0 & 33 & 3 & 2 & 45 & 49 & 0 & 0 & 4 & 42 \\
\hline Leiognathus nuchalis & 254 & 12 & 0 & 3 & 0 & 0 & 21 & 21 & 0 & 10 \\
\hline Acanthopagrus schlegeli & 0 & 0 & 3 & 2 & 0 & 0 & 15 & 2 & 0 & 2 \\
\hline Pagrus major & 22 & 0 & 0 & 0 & 2 & 40 & 0 & 0 & 0 & 0 \\
\hline Terapon jarbua & 0 & 2 & 3 & 0 & 2 & 0 & 0 & 2 & 0 & 3 \\
\hline Ernogrammus hexagrammus & 0 & 0 & 23 & 0 & 0 & 0 & 0 & 4 & 0 & 0 \\
\hline Pholis nebulosa & 12 & 1 & 30 & 2 & 0 & 2 & 7 & 0 & 0 & 25 \\
\hline Enneapterygius sp. & 0 & 0 & 7 & 0 & 0 & 0 & 0 & 0 & 0 & 0 \\
\hline Blenniidae sp. & 0 & 0 & 0 & 0 & 0 & 2 & 0 & 0 & 0 & 0 \\
\hline Omobranchus elegans & 0 & 529 & 118 & 2 & 0 & 9 & 26 & 2 & 2 & 2 \\
\hline Acanthogobius flavimanus & 0 & 48 & 0 & 0 & 37 & 5 & 8 & 0 & 0 & 0 \\
\hline Luciogobius sp. & 0 & 0 & 0 & 0 & 0 & 0 & 4 & 0 & 1 & 0 \\
\hline Synechogobius hasta & 0 & 0 & 4 & 0 & 0 & 0 & 0 & 0 & 0 & 0 \\
\hline Tridentiger trigonocephalus & 19 & 40 & 321 & 0 & 91 & 383 & 45 & 33 & 29 & 71 \\
\hline Gobiidae sp. & 19 & 6 & 0 & 0 & 4 & 27 & 0 & 6 & 43 & 0 \\
\hline Paralichthyidae sp. & 0 & 6 & 0 & 0 & 2 & 0 & 0 & 0 & 0 & 0 \\
\hline Pleuronectidae sp. & 0 & 0 & 2 & 0 & 0 & 2 & 2 & 0 & 0 & 0 \\
\hline Cynoglossidae sp. & 0 & 5 & 0 & 0 & 0 & 3 & 7 & 4 & 2 & 4 \\
\hline Unidentified sp. & 0 & 6 & 0 & 0 & 0 & 0 & 10 & 0 & 0 & 0 \\
\hline No. of species & 7 & 12 & 12 & 7 & 8 & 11 & 14 & 11 & 8 & 25 \\
\hline
\end{tabular}

SSTs of $20.3-23.3^{\circ} \mathrm{C}$. There were 6-508 individuals/ $100 \mathrm{~m}^{3}$ of $H$. otakii collected in January and during November and December 2007 (Table 1), with total lengths ranging from $7.0-20 \mathrm{~mm}(8.6 \pm 2.5 \mathrm{~mm})$, and $79 \%$ occurring at SSTs of $7.6-10.4^{\circ} \mathrm{C}$. Samples collected during January and April 2007 included 755 P. nebulosus individuals $/ 100 \mathrm{~m}^{3}$, with total lengths ranging from $5.0-35 \mathrm{~mm}(21 \pm 10 \mathrm{~mm})$, and $62 \%$ being collected at SSTs of $7.3-8.9^{\circ} \mathrm{C}$. Approximately $10-887$ O. elegans individuals $/ 100 \mathrm{~m}^{3}$ were collected during June and October 2007; their overall lengths ranged from 1.7 to $8.0 \mathrm{~mm}(4.0 \pm 2.3 \mathrm{~mm})$, and $75 \%$ were collected at SSTs of $22.3-23.4^{\circ} \mathrm{C}$. There were 3174 individuals $/ 100 \mathrm{~m}^{3}$ of $S$. japonica collected during July and September 2007; their total lengths were $1.2-9.0 \mathrm{~mm}(3.3 \pm 1.6 \mathrm{~mm})$, and $75 \%$ were collected at SSTs of $22.3-23.4^{\circ} \mathrm{C}$. During May and September 2007, 3-2,035 individuals $/ 100 \mathrm{~m}^{3}$ of $T$. trigonocephalus were collected, with total lengths in the range of $1.5-6.5 \mathrm{~mm}(2.5 \pm 1.1 \mathrm{~mm})$, and $71 \%$ were collected at SSTs of $22.6-23.3^{\circ} \mathrm{C}$.

\section{Diversity and community structure}

Species diversity ranged from 0.24-1.60 (0.92 \pm
0.39) and was lowest in December and highest in August. Cluster analysis based on the number of individuals collected in each month yielded three groups: group A (January-April), group B (MaySeptember), and group C (October-December) (Fig. 3). In group $\mathrm{A}$, the contribution of $P$. nebulosa was highest (93.3\%). However, in group $B$, the contribution of E. japonicus was highest (42.5\%), followed by that of $T$. trigonocephalus at $35.0 \%$. In group C, E. japonicus made the highest contribution at $88.9 \%$, followed by $H$. otakii at $8.4 \%$. Cluster analysis based on the numbers of individuals collected at each station yielded two groups: group A (inside the bays) and group B (outside the bays) (Fig. 4). Although the groups did not correspond exclusively to stations inside and outside the bays, they showed a tendency to divide in this way.

\section{Discussion}

This study compared larval fish compositions in Yeoja Bay and Gamak Bay with the compositions of young fish previously reported by Kim et al. (2009) to further clarify the function of bays including 
Table 3. Spatial variation in the number of individuals for larval fish collected in Gamak Bay between January and December, 2007

\begin{tabular}{|c|c|c|c|c|c|c|c|c|}
\hline \multirow{2}{*}{ Scientific name } & \multicolumn{2}{|c|}{ Inside } & \multicolumn{2}{|c|}{ Eelgrass } & \multirow[b]{2}{*}{ Go1 } & \multicolumn{3}{|c|}{ Outside } \\
\hline & Gi1 & $\mathrm{Gi} 2$ & Ge1 & Ge2 & & Go2 & Go3 & Go4 \\
\hline Engraulis japonicus & 27 & 1,687 & 21 & 362 & 11 & 53 & 54 & 93 \\
\hline Clupea pallasii & 0 & 0 & 4 & 0 & 0 & 0 & 0 & 0 \\
\hline Syngnathus schlegeli & 4 & 0 & 3 & 0 & 0 & 0 & 0 & 0 \\
\hline Sebastes inermis & 3 & 0 & 0 & 0 & 0 & 0 & 0 & 0 \\
\hline Platycephalus indicus & 0 & 0 & 0 & 0 & 1 & 0 & 0 & 0 \\
\hline Hexagrammos otakii & 66 & 44 & 2 & 19 & 24 & 2 & 93 & 13 \\
\hline Liparis tanakai & 0 & 0 & 0 & 0 & 0 & 2 & 0 & 0 \\
\hline Lateolabrax japonicus & 0 & 0 & 2 & 0 & 0 & 2 & 0 & 0 \\
\hline Sillago japonica & 74 & 2 & 15 & 13 & 1 & 0 & 26 & 9 \\
\hline Leiognathus nuchalis & 74 & 0 & 7 & 24 & 0 & 7 & 0 & 4 \\
\hline Haemulidae sp. & 0 & 0 & 0 & 0 & 0 & 1 & 0 & 0 \\
\hline Acanthopagrus schlegelii & 0 & 0 & 0 & 0 & 0 & 0 & 0 & 6 \\
\hline Pagrus major & 0 & 0 & 1 & 0 & 0 & 0 & 10 & 0 \\
\hline Stichaeidae sp. & 5 & 0 & 0 & 0 & 0 & 0 & 0 & 0 \\
\hline Pholis nebulosa & 0 & 7 & 1 & 0 & 0 & 8 & 2 & 0 \\
\hline Blenniidae sp. & 0 & 0 & 0 & 0 & 0 & 1 & 0 & 0 \\
\hline Omobranchus elegans & 169 & 1 & 11 & 43 & 1 & 29 & 91 & 8 \\
\hline Repomucenus sp. & 1 & 1 & 0 & 0 & 0 & 0 & 1 & 0 \\
\hline Acanthogobius flavimanus & 0 & 0 & 7 & 2 & 83 & 25 & 4 & 28 \\
\hline Tridentiger trigonocephalus & 37 & 28 & 446 & 605 & 205 & 35 & 26 & 4 \\
\hline Gobiidae sp. & 245 & 0 & 0 & 0 & 0 & 0 & 0 & 0 \\
\hline Scomber japonicus & 0 & 0 & 0 & 0 & 10 & 1 & 10 & 2 \\
\hline Pleuronectidae sp. & 21 & 0 & 0 & 0 & 0 & 0 & 0 & 0 \\
\hline Cynoglossidae sp. & 0 & 0 & 0 & 0 & 32 & 0 & 26 & 2 \\
\hline Unidentified sp. & 4 & 0 & 0 & 0 & 0 & 0 & 0 & 0 \\
\hline No. of species & 13 & 7 & 12 & 6 & 7 & 12 & 9 & 10 \\
\hline
\end{tabular}

eelgrass (Z. marina) beds as spawning grounds. We found a total of 33 larval fish species in Yeoja and Gamak bays in the South Sea of Korea, whereas a total of 40 young fish species were previously reported from eelgrass beds (Kim et al., 2009). Among these species, 14 species were found as both larval (this study) and young (Kim et al., 2009) fish, including E. japonicus, K. punctatus, Clupea pallasii, H. otakii, A. schlegeli, and Pagrus major (Table 4).

The diversity index was highest for larval fish in August and for young fish in July (Kim et al., 2009). These data indicate that both larval and young fish are most diverse in Yeoja and Gamak bays during warm months. No meaningful differences were found when comparing the species composition and abundance of fish larvae in eelgrass beds (Ye1, Ye2, $\mathrm{Ge} 1$, and $\mathrm{Ge} 2$ ) with those at stations inside and outside the bay (Tables 2, 3).

Hannan and Williams (1998) suggested that optimal recruitment of ocean-spawned juveniles to seagrass habitats may depend on the availability of suitable habitat near a bay entrance. In contrast, in this study, cluster analysis produced two groups, inside (group A) and outside (group B) the bays (Fig. 4). For August, when species diversity was highest, the two bays tended to be slightly divided into inside and outside areas according to the criteria of $25^{\circ} \mathrm{C}$ SST (Fig. 5A) and 32.6 psu salinity (Fig. 5B).

Engraulis japonicus was the predominant species, with larvae appearing in May-November and young fish in April-October (Table 4). Engraulis japonicus is known to spawn from March to November (mainly May-July) along the Korean coast (Lim and Ok, 1977), which is consistent with our results, in which the numbers of larval E. japonicus individuals peaked during June and July (Table 1). However, the larval distribution of $E$. japonicus may not be related to the presence of eelgrass beds, as this species occurs broadly across the South Sea. Hexagrammos otakii larvae appeared in November, December, and January and young fish occurred in February-May, implying that the species uses this area as spawning and nursery grounds. Kang et al. (2004) reported that $H$. otakii spawn from September to December on the west coast of Korea, which is the same as or earlier than our results. This difference may be due to regional variation, as the species spawns from November to January on the south coast of Korea (Kim et al., 1993), which is consistent with our results (Table 1 ). The total lengths of $L$. japonicus 


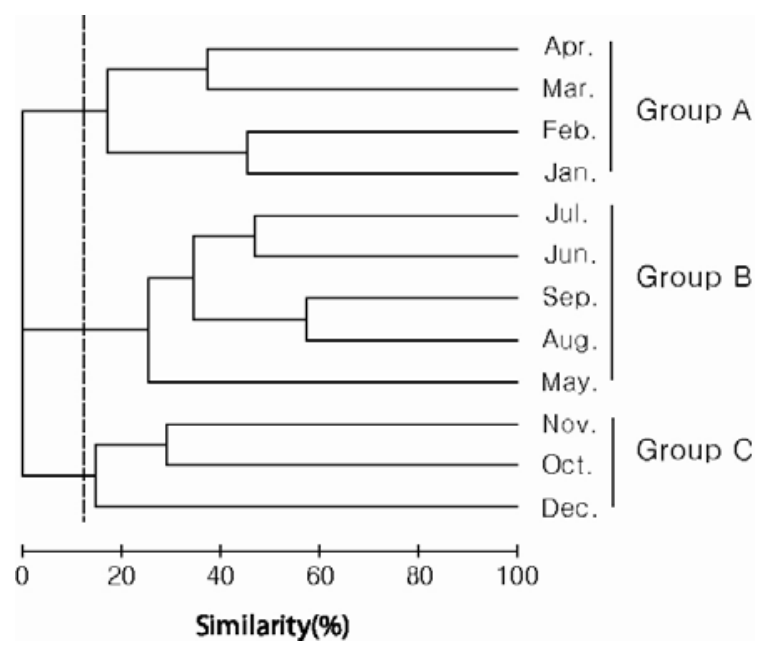

Fig. 3. Dendrogram illustrating relationship among sampling months based on the number of individuals collected in Gamak Bay and Yeoja Bay between January and December, 2007.

juveniles collected during April-May were 19-27 mm, the size estimated by Han et al. (1999) to characterize fish 2-3 months after hatching. This result suggests that this species does not spawn near eelgrass beds, but instead spawns and hatches offshore and approaches bays as it grows, to live as young fish in eelgrass beds with abundant food. However, P. major larvae were collected in June-July and young fish were collected in July, suggesting that $P$. major use the waters inside bays as their spawning and nursery grounds. Pholis nebulosa larvae occurred in January-

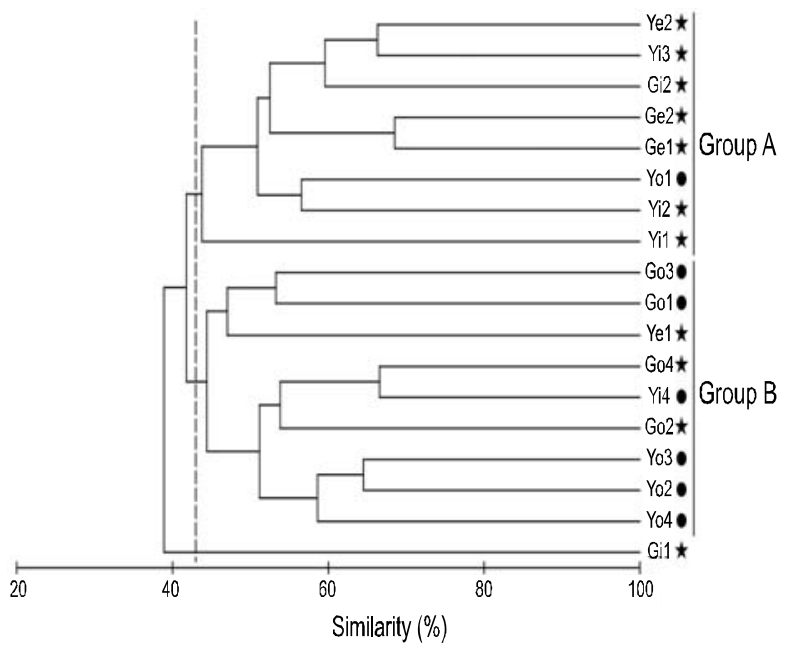

Fig. 4. Dendrogram illustrating relationship among sampling stations based on the number of individuals collected in Gamak Bay and Yeoja Bay between January an December, 2007. Stars and circles indicate inside and outside the bays, respectively.

April and young fish in January-June, suggesting that this fish also uses waters inside the bays as spawning and nursery grounds. When the numbers of larval individuals inside and outside the bays were compared by species, $T$. trigonocephalus was most frequent in the eelgrass beds (Tables 2, 3), suggesting that it is a typical species using the eelgrass beds as a spawning ground. The numbers of larval individuals of $O$. elegans and $P$. nebulosa were higher inside than outside the bays. These species likely use the waters

Table 4. Occurrence of larvae (present study) and young fish (Kim et al., 2009) in the Yeoja Bay and Gamak Bay

\begin{tabular}{|c|c|c|c|c|c|c|c|c|c|c|c|c|c|}
\hline Species & Stage & Jan & Feb & Mar & Apr & May & Jun & Jul & Aug & Sep & Oct & Nov & Dec \\
\hline \multirow{2}{*}{ Engraulis japonicus } & larvae & & & & & & & & & & & & \\
\hline & young & & & & & & & & & & & & \\
\hline \multirow{2}{*}{ Clupea pallasii } & larvae & & 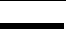 & & & & & & & & & & \\
\hline & young & & & & & - & & & & & & & \\
\hline \multirow{2}{*}{ Konosirus punctatus } & larvae & & & & & & - & & & & & & \\
\hline & young & & & & & & & & & - & & & \\
\hline \multirow{2}{*}{ Hexagrammos otakii } & larvae & L & & & & & & & & & & & \\
\hline & young & & & & & & & & & & & & \\
\hline \multirow{2}{*}{ Lateolabrax japonicus } & larvae & & & & & & & & & & & & \\
\hline & young & & & & & & & & & & & & \\
\hline \multirow{2}{*}{$\begin{array}{l}\text { Acanthopagrus } \\
\text { schlegeli }\end{array}$} & larvae & & & & & & & & & & & & \\
\hline & young & & & & & & & & & & & & \\
\hline \multirow{2}{*}{ Pagrus major } & larvae & & & & & & & & & & & & \\
\hline & young & & & & & & & - & & & & & \\
\hline
\end{tabular}




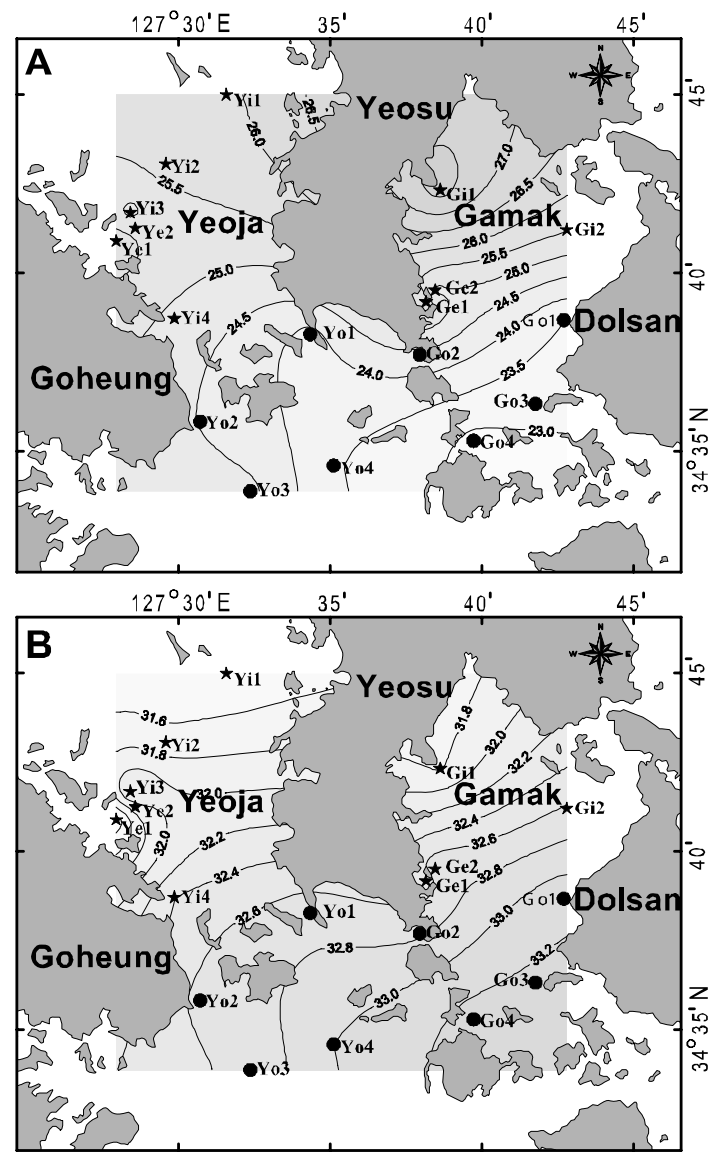

Fig. 5. Isothermal lines (A) and isohalines (B) in Gamak Bay and Yeoja Bay on August, 2007.

inside the bays, which offer abundant food supply and shelter, strategically as spawning and nursery grounds.

\section{References}

An YK, Cho JH, Yoon HS, Park IW, Kim YS, Kim HJ and Choi SD. 2009. Influence of Sargassum beds on the water quality characteristics in Gamak Bay, Korea. Kor J Fish Aquat Sci 42, 284-289.

Cha SS and Park KJ. 1994. Distribution of the ichthyoplankton in Kwangyang bay. Kor J Ichthyol 6, 60-70.

Han KH, Hong JS, Kim YS and Jeon KA. 2003. Species composition and seasonal variations of ichthyoplankton in coastal waters of Yeongil bay, Korea. Kor J Ichthyol 15, 87-94.

Han KH, Kim DY, Jin DS and Shin SS. 2001. Seasonal variation and species composition of ichthyoplankton in Sunchon bay, Korea. Kor J Ichthyol 13, 136-142.

Han KH, Lee WK, Yang SW, Oh SH and Shin SS. 1999. Early life history of the sea bass, Lateolabrax japonicus (Cuvier). Kor J Ichthyol 11, 94-101.

Hannan JC and Williams RJ. 1998. Recruitment of juvenile marine fishes to seagrass habitat in a temperate Australian estuary. Estuaries 21, 29-51.

Kang HW, Chung EY and Kim JH. 2004. Sexual maturation and spawning characteristics in greenling, Hexagrammos otakii of the west coast in Korea. J Aquaculture 17, 30-38.

Kim JB, Ryu JH and Kim JK. 2009. Comparative analysis of fish community structure between Eelgrass (Zostera marina L.) beds and adjacent unvegetated area in Southern Korea. J Fish Sci Technol 12, 60-69.

Kim JK, Choi JI, Chang DS, Na JT and Kim UK. 2003. Distribution of fish eggs, larvae and juveniles around the Youngsan River estuary. J Kor Fish Soc 36, 486494.

Kim UK, Han KH and Kim BH. 1993. The embryonic and larval development of the Greenling, Hexagrammos otakii Jordan et Starks. Kor J Ichthyol 5, 151-159.

Kim UK, Han KH and Kim CB. 1994. Distribution of ichthyoplankton in Asan bay, Bull Kor Fish Soc 27, 620-632.

Lasker, R. Use of fish eggs and larvae in probing some major problems in fisheries and aquaculture. Amer Fish Soc Sym 2, 1-16.

Lim JY and Ok IS. 1977. Studies on the occurrence and distribution of eggs and Larvae of anchovy in the Korean waters. Bull Fish Res Dev Agency, 16, 74-86.

Margalef R. 1963. On certain unifying principles in ecology. Amer Nature 97, 357-374.

Margalef R. 1978. Sampling design: Some examples. In: Sournia A, ed. Phytoplankton Manual, UNESCO, Paris, 17-31.

Okiyama M. 1988. An Atlas of the Early Stage Fishes in Japan. Tokai Univ Press, 1154pp.

Pielou EC. 1966. The measurement of diversity in different of the biologicial collection. J Theoret Biol 13, 131144.

Shannon EC and Weaver W. 1948. The Mathematical Theory of Communication. University of Illinois, 4th ed. Prentice Hall, New Jersey, 663pp.

Yoo JM and Cha SS. 1988. Variation of abundances of ichthyoplankton in Kwangyang Bay, Ocean Res 10, 79-84.

Yoo JM, Kim S and Lee EK. 1993. The effect of freshwater input on the abundances of fish eggs and larvae during on rainy season in Yoja Bay, Korea. Ocean Res 15, 37-42.

Yoo JM, Kim S, Lee EK and Lee JS. 1992. The distribution of ichthyoplankton in Chinhae Bay, Ocean Res 14, 77-87.

Zar JH. 1999. Biostatistical Analysis, 4th ed. Prentice Hall, NewJersey, 663 pp.

(Received 12 August 2010; Revised 19 October 2010; Accepted 9 March 2011) 